Biography

\title{
Dr. A. Mahadevaiah: A Legend
}

Vijayendra Honnurappa ${ }^{1}$

${ }^{1}$ Vijaya ENT Care Centre, Super Speciality Otology Centre, Bangalore, Karnataka, India

Ann Otol Neurotol ISO 2018;1:5-6

Dr. A. Mahadevaiah-A Legend is the biography of a great and noble human being who is none other than Dr. Agadurappa Mahadevaiah. Dr. Agadurappa Mahadevaiah, a great and noble human being, was born on August 16, 1935, in the outskirts of Bangalore. Dr. Mahadevaiah was born on the August 16,1935 , in the outskirts of Bangalore. He was the first son to Mr Agadurappa and Mrs Nanjamma along with six brothers and three sisters. His rural background and sense of human service influenced his aspirations to become a doctor and motivated him to enter the medical profession. However, during those days, the independence movement in our country was active. Dr. Mahadevaiah used to take part in the Bhoodan movement launched by Vinoba Bhava during his school holidays in the 1950s.

He joined the MBBS course by merit at the Bangalore Medical College in 1956. As a medical student, he aspired to become an ENT (ear-nose-throat) surgeon because of a friend who was moderately deaf and could not get his deficiency repaired due to monetary insufficiency. This made Dr. Mahadevaiah all the more determined, and he adored the role of an ENT surgeon to restore the hearing in moderately deaf people.

Since the ENT faculty of India was grossly underdeveloped and Dr. Mahadevaiah had immense thirst for otology, he went to the United States in 1963 with the hope of acquiring otologic surgical skills. He then proceeded to Canada for an internship of 1.5 years in neurosurgery under Dr. Eric Peterson and another 6 months under Dr. Guy Labramboise at the Ottawa General Hospital. To obtain his ENT training, he went back to United States, but it necessitated a 1-year residency program in general surgery that he successfully accomplished at the Norwalk Hospital, Norwalk, Connecticut. This was the turning point in Dr. Mahadevaiah's life. He aspired for otology program and applied for the same. However, there was immense competition for ENT training program. He was put on a waiting list for several months. Probably, this must have been the most depressing phase for a man with such a positive, blossoming, and optimistic outlook.

During the waiting period, to prolong his stay in the United States, he decided to undergo some other residency programs and signed a contract with the pediatric residency at the Hale University in New Heaven, Connecticut. Before starting that residency, fortunately, with the blessings of God, he got ENT residency in a second interview at St. Luke's Hospital, New York, with the help of Dr. Stanley Whitefield, the Director of the ENT Department. When he joined the residency in 1965 at St. Luke's Hospital, he was provided with 100 temporal bones by the Lempert Institute. Dr. Mahadevaiah utilized the opportunity and dissected several temporal bones to master temporal anatomy.

As a resident, he performed more than 714 ENT surgeries that included 24 stapedectomies and 2 sphenoethmoidectomies and open external ethmoidectomy for repair of cerebrospinal fluid (CSF) leak. In 1968, he obtained his American Board $(\mathrm{AB})$ degree in otorhinolaryngology at the first attempt. This is one of the most difficult examinations in which a candidate is questioned by 25 examiners. After the $A B$ examination, he received a fellowship to perform research in otology at the Columbia University. In October 1969, he left the United States for India to serve the fellow Indians.

He forfeited a lucrative and fanciful career in the United States for the benefit of poor and downtrodden. Many of his professors in the United States refused to relieve him, but Dr. Mahadevaiah was steadfast in his resolve to return to India to live with his people and train young ENT surgeons.

At this juncture, we must reemphasize this commitment toward his country and fellow countrymen. He was a great nationalist with deep belief in the Gandhian principles.

Having landed in India, he started his ENT practice in a small way and also had a short stint of government service as a lecturer at the Bangalore Medical College. At that time, there were only few otologists in our country to perform ear surgeries. Because Dr. Mahadevaiah had acquired advanced otology training, he started his practice in Bangalore, which slowly and steadily established his name. He was also associated with the National Institute of Mental Health and Neurosciences (NIMHANS), Bangalore as an ENT skull base surgeon and was the first to repair CSF leak by external ethmoid route using a microscope.

\section{Address for correspondence} Vijayendra Honnurappa, DLO, MS, Vijaya ENT Care Centre, No.1, 9th Cross, Malleshwaram, Bangalore 560003, Karnataka, India (email id: vijayentblr@gmail.com)
DOI https://doi.org/

10.1055/s-0037-1608755.
Copyright @2018 Indian Society of Otology
License terms

() (1) $\Theta \circledast$ 
As years started rolling by, he felt the need to have his own organization and this saw the birth of the Basavanagudi ENT Care Centre, Bangalore, which is the alma mater to many practicing ENT surgeons.

After the commencement of his ENT practice at the Basavanagudi ENT Care Centre in 1976, there was no looking back. He performed more than 25,000 ear surgeries and an innumerable number of nasal surgeries and rhinoplasties. He could have accomplished all these in the United States with monetary gains, but he considered honor and pride to be superior to the external advantages of the rank. He was a noncommercial person and was very particular that no one should walk out of his center for want of money to get cured of one's disease.

He initiated temporal bone dissection and live surgical demonstration in his own center along with Dr. Vijayendra. They conducted more than 25 courses in the past decade that were widely attended by ENT surgeons throughout the country.
He was the President of the Association of Otolaryngologists (AOI) from 1995 to 1996, the Founder President of the Indian Society of Otology (ISO) from 1991 to 1996 , and the President of the Indian Society of Rhinology from 2004 to 2005. He also served as the President of the Karnataka State Branch and Bangalore branch of AOI. The dream of Dr. Mahadevaiah to write the book "Surgical Techniques in Chronic Otitis Media and Otosclerosis" was recently achieved.

On the personal front, he was blessed with a beloved wife and two daughters. As a human being, one has duties to God, one's family, neighbors, and countrymen. Dr. Mahadevaiah accomplished his duties to God in a divine manner. To his family members, he was an excellent husband and father. For his fellow countrymen, he practiced charity, honesty, and served his best.

What has been described above is only the tip of the iceberg of Dr. Mahadevaiah's life. 